\title{
Embelin-Induced Phosphatidylserine Translocation in the Erythrocyte Cell Membrane
}

\author{
Ghada Bouguerra $^{\mathrm{a}, \mathrm{b}} \quad$ Omar Aljanadi $^{\mathrm{a}}$ Rosi Bissinger ${ }^{\mathrm{a}} \quad$ Salem Abbès ${ }^{\mathrm{b}} \quad$ Florian Lang $^{\mathrm{a}}$ \\ aDepartment of Physiology, University of Tuebingen, Tuebingen, Germany; ' Laboratoire d'Hématologie \\ Moléculaire et Cellulaire, Institut Pasteur de Tunis, Université Tunis-El Manar, Tunis, Tunisia
}

\section{Key Words}

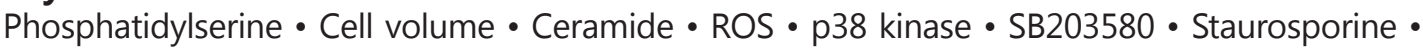
Eryptosis

\begin{abstract}
Background/Aims: The antihelminthic, contraceptive, anti-inflammatory and anticancer phytochemical embelin is at least in part effective against malignancy by inducing suicidal death or apoptosis of tumor cells. Erythrocytes are similarly able to enter suicidal death or eryptosis, which is characterized by cell shrinkage and cell membrane scrambling with phosphatidylserine translocation to the erythrocyte surface. Signaling of eryptosis includes increase of cytosolic $\mathrm{Ca}^{2+}$-activity $\left(\left[\mathrm{Ca}^{2+}\right]_{i}\right)$, ceramide formation, oxidative stress as well as activation of p38 kinase and protein kinase C (PKC). The present study tested, whether and how embelin induces eryptosis. Methods: Phosphatidylserine exposure at the cell surface was estimated from annexin $V$ binding, cell volume from forward scatter, $\left[\mathrm{Ca}^{2+}\right]_{i}$ from Fluo3fluorescence, ceramide abundance utilizing specific antibodies and reactive oxygen species (ROS) from 2',7'-dichlorodihydrofluorescein diacetate (DCFDA) fluorescence. Results: A 48 hours exposure of human erythrocytes to embelin $(\geq 25 \mu \mathrm{M})$ significantly increased the percentage of annexin-V-binding cells and hemolysis. Embelin did not significantly modify $\left[\mathrm{Ca}^{2+}\right]$. The effect of embelin on annexin-V-binding was not blunted by removal of extracellular $\mathrm{Ca}^{2+}$, by p38 kinase inhibitor SB203580 $(2 \mu \mathrm{M})$ or by PKC inhibitor staurosporine $(1 \mu \mathrm{M})$. Embelin did, however, significantly increase the ceramide abundance. Conclusions: Embelin stimulates phospholipid scrambling of the erythrocyte cell membrane, an effect involving ceramide formation.
\end{abstract}

(C) 2015 The Author(s)

Published by S. Karger AG, Basel

\section{Introduction}

Embelin (2,5-dihydroxy-3-undecyl-1,4-benzoquinone), a phytochemical isolated from Embelia ribes [1], has antihelminthic [2], contraceptive [2], anti-inflammatory [3-6] and anticancer [1-4, 6-11] potency, as well as photosensitizing [1] and radiation sensitizing [12] 
property. Embelin has further been shown to decrease cardiac injury following experimental myocardial infarction [13] and to protect cells against UVB-induced oxidative damage [14], but to aggravate the encephalopathy following neonatal hypoxia-ischemia [15].

The anticancer activity of embelin has in part been attributed to stimulation of apoptosis $[6-8,11,16-32]$. Mechanisms mediating the effects of embelin include mitochondrial depolarization [22, 23, 27, 29, 31], induction of oxidative stress [17], inhibition of X-linked inhibitor of the apoptosis protein (XIAP) $[3,5,10,11,16,19,20,24,30,32-36]$, of PTEN/ Akt/mTOR/S6K1 signaling $[37,38]$ and of the transcription factors NF- $\kappa B[2,11,16,25$, $39]$ and STAT3 $[3,6,18,37]$, increase of intracellular free $\mathrm{Ca}^{2+}$ concentration $\left(\left[\mathrm{Ca}^{2+}\right]_{\mathrm{i}}\right)[40]$, upregulation of TRAIL receptors DR4/DR5 [19] and Bax [7, 23, 31], as well as activation of p38 kinase [17, 32], Jun kinase [17], p53 transcription factor [6, 22, 28, 32] and caspases $[7,8,11,17,19,20,22,23,28,31,34,38]$. Moreover, embelin may sensitize tumor cells to the anticancer effect of peroxisome proliferator-activated receptor-gamma (PPARgamma) ligands [41].

Erythrocytes may, similar to apoptosis of nucleated cells, enter suicidal death or eryptosis, which is characterized by cell shrinkage [42] and phospholipid scrambling of the cell membrane leading to phosphatidylserine translocation to the cell surface [43]. Signaling involved in the triggering of eryptosis include oxidative stress [43], $\mathrm{Ca}^{2+}$ entry with increase of cytosolic $\mathrm{Ca}^{2+}$ activity $\left(\left[\mathrm{Ca}^{2+}\right]_{\mathrm{i}}\right)[43]$, ceramide [44], energy depletion [43], activated caspases $[43,45,46]$, stimulation of casein kinase $1 \alpha$ [47], Janus-activated kinase JAK3 [48], protein kinase C [49] and p38 kinase [50], as well as decreased activity of AMP activated kinase AMPK [51], cGMP-dependent protein kinase [52], PAK2 kinase [53] and sorafenib/ sunitinib sensitive kinases $[43,54,55]$. A wide variety of xenobiotics have previously been shown to trigger eryptosis [43, 56-84].

The present study tested the influence of embelin on eryptosis. To this end, human erythrocytes from healthy volunteers were treated with embelin and phosphatidylserine surface abundance and cell volume determined by flow cytometry.

\section{Materials and Methods}

\section{Erythrocytes, solutions and chemicals}

Fresh Li-Heparin-anticoagulated blood samples were kindly provided by the blood bank of the University of Tübingen. The study is approved by the ethics committee of the University of Tübingen $(184 / 2003 \mathrm{~V})$. The blood was centrifuged at $120 \mathrm{xg}$ for $20 \mathrm{~min}$ at $21^{\circ} \mathrm{C}$ and the platelets and leukocytescontaining supernatant was disposed. Erythrocytes were incubated in vitro at a hematocrit of $0.4 \%$ in Ringer solution containing (in mM) $125 \mathrm{NaCl}, 5 \mathrm{KCl}, 1 \mathrm{MgSO}_{4}, 32 \mathrm{~N}$-2-hydroxyethylpiperazine-N-2-ethanesulfonic acid (HEPES), 5 glucose, $1 \mathrm{CaCl}_{2} ; \mathrm{pH} 7.4$ at $37^{\circ} \mathrm{C}$ for 48 hours. Where indicated, erythrocytes were exposed to embelin (Enzo Life Sciences, Lörrach, Germany) which was dissolved in DMSO (Carl Roth, Karlsruhe, Germany).

\section{Annexin-V-binding and forward scatter}

After incubation under the respective experimental condition, a $150 \mu \mathrm{L}$ cell suspension was washed in Ringer solution containing $5 \mathrm{mM} \mathrm{CaCl}_{2}$ and then stained with Annexin-V-FITC (1:200 dilution; ImmunoTools, Friesoythe, Germany) in this solution at $37^{\circ} \mathrm{C}$ for $20 \mathrm{~min}$ under protection from light. The annexin $\mathrm{V}$ abundance at the erythrocyte surface was subsequently determined on a FACS Calibur (BD, Heidelberg, Germany). Annexin V binding was measured with an excitation wavelength of $488 \mathrm{~nm}$ and an emission wavelength of $530 \mathrm{~nm}$. A marker (M1) was placed to set an arbitrary threshold between annexin V-binding cells and control cells. The same threshold was used for untreated and embelin treated erythrocytes. A dot plot of forward scatter (FSC) vs. side scatter (SSC) was set to linear scale for both parameters. The threshold of forward scatter was set at the default value of " 52 ".

Intracellular $\mathrm{Ca}^{2+}$

After incubation, erythrocytes were washed in Ringer solution and then loaded with Fluo-3/AM (Biotium, Hayward, USA) in Ringer solution containing $5 \mathrm{mM} \mathrm{CaCl}_{2}$ and $5 \mu \mathrm{M}$ Fluo-3/AM. The cells were 


\section{Cellular Physiology Cell Physiol Biochem 2015;37:1629-1640 \begin{tabular}{c|c|c|c|} 
DOI: 10.1159/000438529 & O 2015 The Author(s). Published by S. Karger AG, Basel \\
www.karger.com/cpb
\end{tabular} \\ Bouguerra et al.: Embelin-Induced Eryptosis}

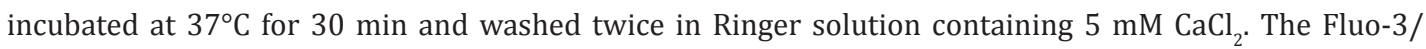
AM-loaded erythrocytes were resuspended in $200 \mu \mathrm{L}$ Ringer. Then, $\mathrm{Ca}^{2+}$-dependent fluorescence intensity was measured with an excitation wavelength of $488 \mathrm{~nm}$ and an emission wavelength of $530 \mathrm{~nm}$ on a FACS Calibur.

\section{Ceramide abundance}

For the determination of ceramide, a monoclonal antibody-based assay was used. After incubation, a $100 \mu \mathrm{L}$ cell suspension was stained for 1 hour at $37^{\circ} \mathrm{C}$ with $1 \mu \mathrm{g} / \mathrm{mL}$ anti-ceramide antibody (clone MID 15B4, Alexis, Grünberg, Germany) in PBS containing 0.1\% bovine serum albumin (BSA) at a dilution of 1:10. The samples were washed twice with PBS-BSA. Subsequently, the cells were stained for 30 minutes with polyclonal fluorescein isothiocyanate (FITC) conjugated goat anti-mouse IgG and IgM specific antibody (Pharmingen, Hamburg, Germany) diluted 1:50 in PBS-BSA. Unbound secondary antibody was removed by repeated washing with PBS-BSA. The samples were then analyzed by flow cytometric analysis with an excitation wavelength of $488 \mathrm{~nm}$ and an emission wavelength of $530 \mathrm{~nm}$.

Reactive oxygen species (ROS)

Oxidative stress was determined utilizing 2', 7'-dichlorodihydrofluorescein diacetate (DCFDA). After incubation, a $150 \mu \mathrm{L}$ suspension of erythrocytes was washed in Ringer solution and then stained with DCFDA (Sigma, Schnelldorf, Germany) in Ringer solution containing DCFDA at a final concentration of 10 $\mu \mathrm{M}$. Erythrocytes were incubated at $37^{\circ} \mathrm{C}$ for $30 \mathrm{~min}$ in the dark and then washed three times in Ringer solution. The DCFDA-loaded erythrocytes were resuspended in $200 \mu \mathrm{L}$ Ringer solution and ROS-dependent fluorescence intensity was measured at an excitation wavelength of $488 \mathrm{~nm}$ and an emission wavelength of $530 \mathrm{~nm}$ on a FACS Calibur (BD).

Hemolysis

In order to determine hemolysis, the samples were centrifuged ( $3 \mathrm{~min}$ at $1600 \mathrm{rpm}$, room temperature) after incubation under the respective experimental conditions and the supernatants were harvested. As a measure of hemolysis, the haemoglobin $(\mathrm{Hb})$ concentration of the supernatant was determined photometrically at $405 \mathrm{~nm}$. The absorption of the supernatant of erythrocytes lysed in distilled water was defined as $100 \%$ hemolysis. Hemolysis is expressed in \% in order to allow comparison with \% annexin V binding cells.

\section{Statistics}

Data are expressed as arithmetic means \pm SEM. As indicated in the figure legends, statistical analysis was made using ANOVA with Tukey's test as post-test and t test as appropriate. $\mathrm{n}$ denotes the number of different erythrocyte specimens studied. Since different erythrocyte specimens used in distinct experiments are differently susceptible to triggers of eryptosis, the same erythrocyte specimens have been used for control and experimental conditions.

\section{Results}

The present study explored, whether embelin stimulates eryptosis, the suicidal erythrocyte death. Hallmarks of eryptosis include cell membrane scrambling with phosphatidylserine translocation to the cell surface. In order to identify erythrocytes with phosphatidylserine at their surface, the cells were incubated with phosphatidylserine-binding FITC-labeled annexin-V, which was determined by flow cytometry. The erythrocytes were analyzed following incubation for 48 hours in Ringer solution without or with embelin (10 $50 \mu \mathrm{M}$ ). As illustrated in Fig. 1B, a 48 hours exposure to embelin increased the percentage of annexin-V-binding erythrocytes, an effect reaching statistical significance at $25 \mu \mathrm{M}$ embelin.

The suicidal erythrocyte death could involve hemolysis. In order to estimate the effect of embelin on hemolysis, the haemoglobin concentration in the supernatant was determined. As a result, a 48 hours incubation with embelin resulted in hemolysis, an effect reaching statistical significance at $25 \mu \mathrm{M}$ embelin (Fig. 2). 


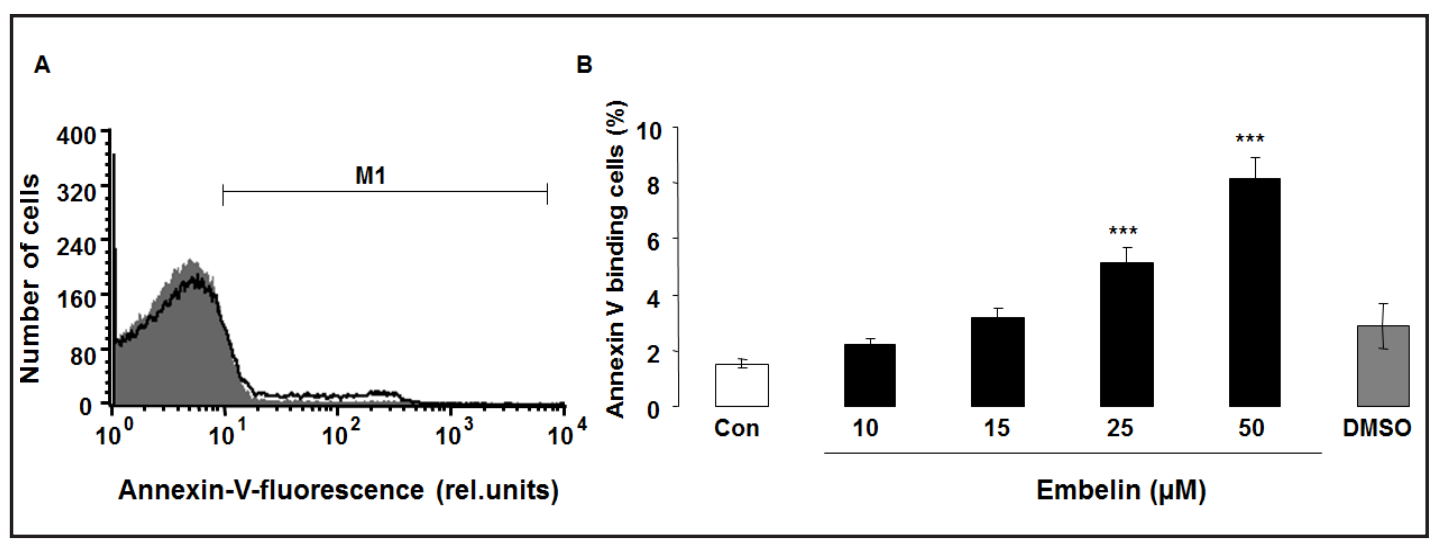

Fig. 1. Effect of embelin on phosphatidylserine exposure. (A) Original histogram of annexin-V-binding of erythrocytes following exposure for 48 hours to Ringer solution without (grey area) and with (black line) presence of $50 \mu \mathrm{M}$ embelin. M1 indicates the annexin-V-fluoresence defining the percentage of annexinV-binding erythrocytes. (B) Arithmetic means \pm SEM $(n=12)$ of erythrocyte annexin-V-binding following incubation for 48 hours to Ringer solution without (white bar) or with (black bars) presence of embelin (10 $-50 \mu \mathrm{M})$ or of the solvent DMSO (grey bar). ${ }^{* * *}(\mathrm{P}<0.001)$ indicates significant difference from the absence of embelin (ANOVA).

Fig. 2. Effect of embelin on hemolysis. Arithmetic means \pm SEM of erythrocyte hemolysis ( $\mathrm{n}$ = 7) following incubation for 48 hours to Ringer solution without (white bar) or with (black bars) presence of embelin (10-50 $\mu \mathrm{M}$ ) or of the solvent DMSO (grey bar). ${ }^{* *}(\mathrm{P}<0.01)$, *** $(\mathrm{P}<0.001)$ indicate significant difference from the absence of embelin (ANOVA).

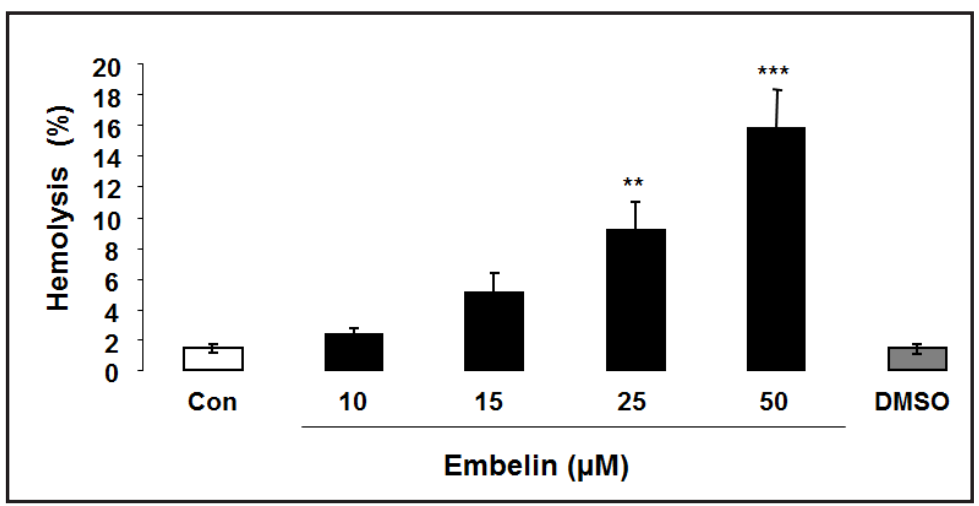

Forward scatter was determined in order to determine whether embelin modifies cell volume. As a result, the forward scatter was similar following a 48 hours incubation without $(510 \pm 5$, a.u., $\mathrm{n}=12)$ and with $10 \mu \mathrm{M}(520 \pm 5$, a.u., $\mathrm{n}=12), 15 \mu \mathrm{M}(522 \pm 4$, a.u., $\mathrm{n}=12), 25$ $\mu \mathrm{M}(518 \pm 6$, a.u., $\mathrm{n}=12)$ and $50 \mu \mathrm{M}$ embelin (506 \pm 6 , a.u., $\mathrm{n}=12)$. Accordingly, embelin did not significantly modify average forward scatter.

In order to determine whether embelin modifies cytosolic $\mathrm{Ca}^{2+}$ activity $\left(\left[\mathrm{Ca}^{2+}\right]_{\mathrm{i}}\right)$, Fluo3 fluorescence was taken as measure of $\left[\mathrm{Ca}^{2+}\right]_{\mathrm{i}^{*}}$. As illustrated in Fig. 3A, B, the Fluo3 fluorescence was similar following a 48 hours incubation without and with embelin $(10-50 \mu \mathrm{M})$. Accordingly, embelin did not significantly modify $\left[\mathrm{Ca}^{2+}\right]_{\mathrm{i}}$. An additional series of experiments explored whether embelin-induced translocation of phosphatidylserine to the cell surface was dependent on entry of extracellular $\mathrm{Ca}^{2+}$. To this end, erythrocytes were incubated for 48 hours in the absence or presence of $50 \mu \mathrm{M}$ embelin, either in the presence or nominal absence of extracellular $\mathrm{Ca}^{2+}$. As illustrated in Fig. 3C, removal of extracellular $\mathrm{Ca}^{2+}$ did not significantly blunt the effect of embelin on annexin-V-binding. Instead, embelin significantly increased the percentage of annexin-V-binding erythrocytes to similarly high levels in the absence and in the presence of extracellular $\mathrm{Ca}^{2+}$. Thus, triggering of phosphatidylserine translocation by embelin was due to mechanisms other than entry of extracellular $\mathrm{Ca}^{2+}$.

Triggering of phosphatidylserine translocation to the erythrocyte surface may further involve oxidative stress. Reactive oxygen species (ROS) was thus quantified utilizing 2 ', $7^{\prime}$-dichlorodihydrofluorescein diacetate (DCFDA). As a result, the DCFDA fluorescence 


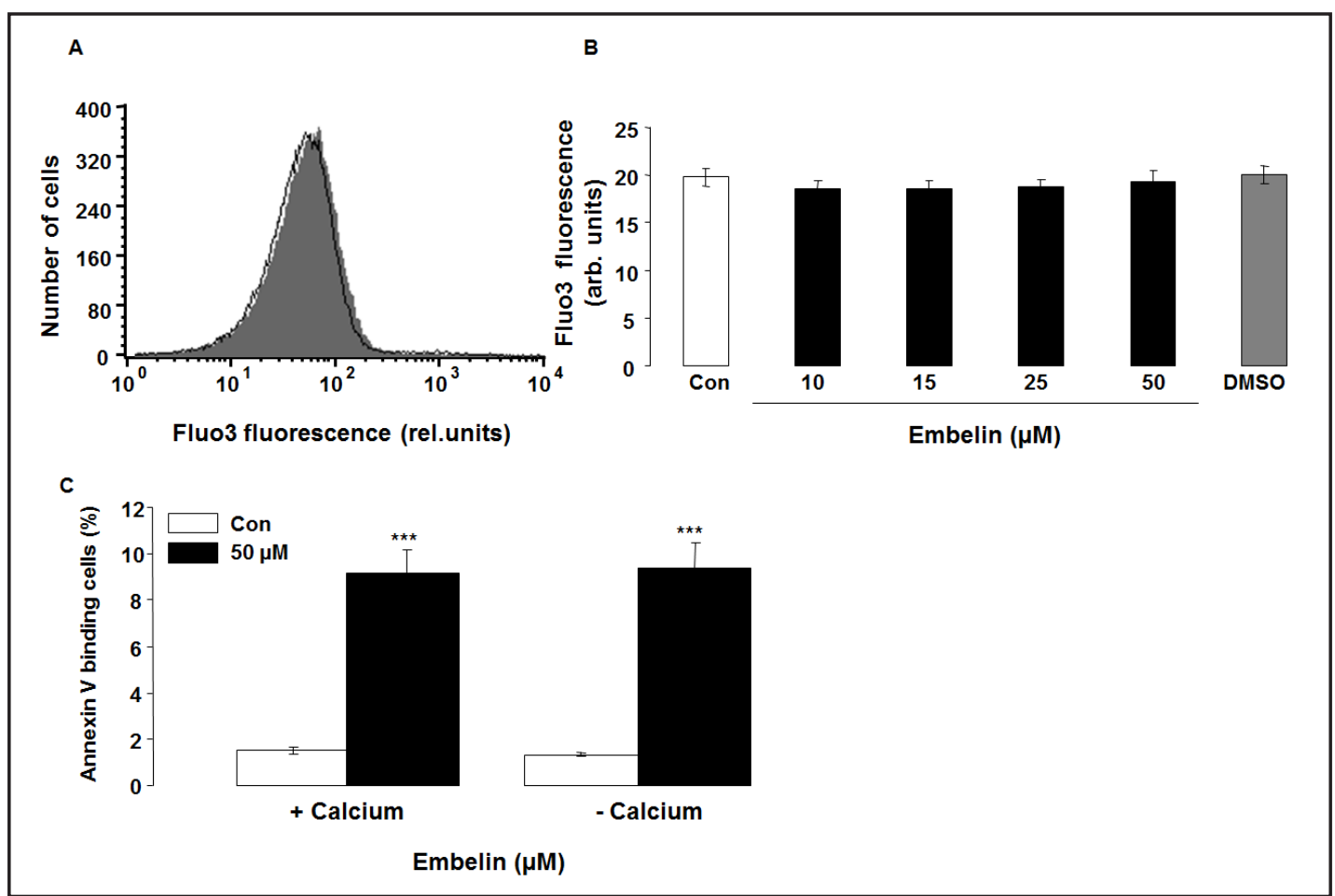

Fig. 3. Erythrocyte $\mathrm{Ca}^{2+}$ activity and $\mathrm{Ca}^{2+}$ insensitivity of embelin-induced phosphatidylserine exposure. (A) Original histogram of Fluo3 fluorescence in erythrocytes following exposure for 48 hours to Ringer solution without (grey area) and with (black line) presence of embelin $(50 \mu \mathrm{M})$. (B) Arithmetic means \pm SEM $(n=12)$ of the Fluo3 fluorescence (arbitrary units) in erythrocytes exposed for 48 hours to Ringer solution without (white bar) or with (black bars) presence of embelin $(10-50 \mu \mathrm{M})$ or of the solvent DMSO (grey bar). (C) Arithmetic means \pm SEM $(n=10)$ of annexin-V-binding of erythrocytes after a 48 hours treatment with Ringer solution without (white bars) or with (black bars) embelin $\left(50 \mu \mathrm{M}\right.$ ) in the presence (left bars, $+\mathrm{Ca}^{2+}$ ) and absence (right bars, $\left.-\mathrm{Ca}^{2+}\right)$ of $\mathrm{Ca}^{2+}$.** $(\mathrm{P}<0.001)$ indicates significant difference from the absence of embelin (ANOVA).

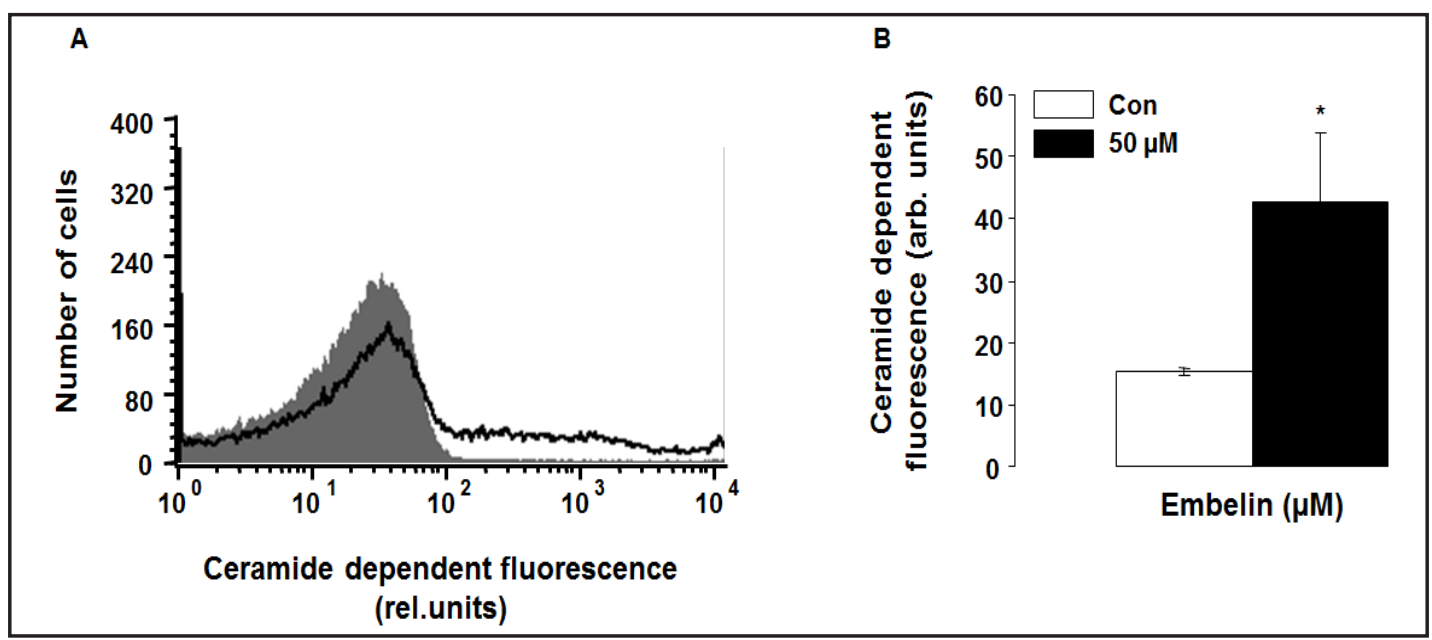

Fig. 4. Effect of embelin on ceramide abundance. (A) Original histogram of ceramide abundance at the erythrocyte surface following exposure for 48 hours to Ringer solution without (grey area) and with (black line) presence of $50 \mu \mathrm{M}$ embelin. (B) Arithmetic means \pm SEM $(n=9)$ of erythrocyte ceramide abundance following incubation for 48 hours to Ringer solution without (white bar) or with (black bar) presence of embelin $(50 \mu \mathrm{M}) . *(\mathrm{P}<0.05)$ indicates significant difference from the absence of embelin $(\mathrm{t}$ test).

\section{KARGER}




\section{Cellular Physiology Cell Physiol Biochem 2015;37:1629-1640

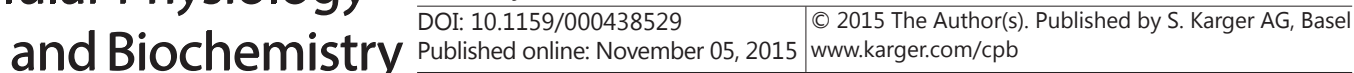 \\ Bouguerra et al.: Embelin-Induced Eryptosis}

was similar in the absence $(16.9 \pm 1.5$ a.u., $\mathrm{n}=14)$ and presence $(15.6 \pm 1.0$ a.u., $\mathrm{n}=14)$ of $50 \mu \mathrm{M}$ embelin. For comparison, a $10 \mathrm{~min}$ exposure of erythrocytes to $0.3 \mathrm{mM}$ tertbutylhydroperoxide (TBOOH) was followed by a significant increase of DCFDA fluorescence $(224.6 \pm 32.5$ a.u., $\mathrm{n}=6)$.

An additional series of experiments explored whether the embelin-induced phosphatidylserine translocation was dependent on activation of p38 kinase. To this end, erythrocytes were exposed for 48 hours to $50 \mu \mathrm{M}$ embelin in the absence or presence of the p38 kinase inhibitor SB203580 $(2 \mu \mathrm{M})$. As a result, the effect of embelin $(50 \mu \mathrm{M})$ on annexinV-binding was similar in the presence $(5.4 \pm 0.9 \%, \mathrm{n}=9)$ and absence $(5.8 \pm 0.8 \%, \mathrm{n}=9)$ of p38 kinase inhibitor SB203580.

An additional series of experiments explored whether the embelin-induced phosphatidylserine translocation was dependent on activation of protein kinase C. To this end, erythrocytes were exposed for 48 hours to $50 \mu \mathrm{M}$ embelin in the absence or presence of the PKC inhibitor staurosporine $(1 \mu \mathrm{M})$. As a result, the effect of embelin on annexin-Vbinding was similar in the presence $(8.2 \pm 0.3 \%, \mathrm{n}=7)$ and absence $(8.1 \pm 0.4 \%, \mathrm{n}=7)$ of PKC inhibitor staurosporine.

Stimulators of eryptosis in the absence of increased $\left[\mathrm{Ca}^{2+}\right]_{i}$ include ceramide. Thus, specific antibodies were utilized to quantify ceramide abundance at the erythrocyte surface. As illustrated in Fig. 4, a 48 hours exposure to embelin $(50 \mu \mathrm{M})$ significantly increased the ceramide abundance at the erythrocyte surface.

\section{Discussion}

The present observations uncover a novel effect of embelin, i.e. the stimulation of erythrocyte cell membrane scrambling with phosphatidylserine translocation to the erythrocyte surface. The embelin concentration $(25 \mu \mathrm{M})$ required for stimulation of erythrocyte cell membrane scrambling was within the range of concentrations observed in vivo [85] and of those previously shown to trigger tumor cell apoptosis in vitro [86]. Embelin did not significantly modify erythrocyte forward scatter and had thus little effect on cell volume.

Embelin further did not appreciably modify cytosolic $\mathrm{Ca}^{2+}$ activity $\left(\left[\mathrm{Ca}^{2+}\right]_{\mathrm{i}}\right)$. An increase of $\left[\mathrm{Ca}^{2+}\right]_{\mathrm{i}}$ would be expected to trigger cell shrinkage by activating $\mathrm{Ca}^{2+}$ sensitive $\mathrm{K}^{+}$channels with $\mathrm{K}^{+}$exit, cell membrane hyperpolarization, $\mathrm{Cl}^{-}$exit and thus cellular loss of $\mathrm{KCl}$ with water [42]. The failure of embelin to increase $\left[\mathrm{Ca}^{2+}\right]_{\mathrm{i}}$ provides an explanation for the lack of cell shrinkage following embelin treatment. The present observations do not exclude minor alterations of $\left[\mathrm{Ca}^{2+}\right]_{\mathrm{i}}$. However, the embelin induced phosphatidylserine translocation does not require entry of extracellular $\mathrm{Ca}^{2+}$ with subsequent increase of $\left[\mathrm{Ca}^{2+}\right]_{\mathrm{i}}$.

In contrast to observations in nucleated cells [17], embelin did not increase the abundance of reactive oxygen species (ROS), a well known trigger of eryptosis [43]. The embelin induced eryptosis was further not significantly blunted by p38 kinase inhibitor SB203580, an observation again contrasting observations in nucleated cells [17, 32]. Moreover, embelin induced cell membrane scrambling was insensitive to the PKC inhibitor staurosporine.

The stimulation of cell membrane phosphatidylserine translocation was paralleled by and at least in part due to increased abundance of ceramide, which may trigger erythrocyte cell membrane scrambling even in the absence of increased $\left[\mathrm{Ca}^{2+}\right]_{i}[43]$.

Besides its effect on eryptosis, embelin triggered hemolysis. The rate of hemolysis even exceeded that of eryptosis. A purpose of eryptosis is the clearance of defective erythrocytes prior to hemolysis [43], thus preventing release of haemoglobin, which is otherwise filtered in renal glomeruli, precipitates in renal tubular fluid and thus occludes nephrons [87]. Eryptosis further serves the clearance of Plasmodium infected erythrocytes in malaria and thus favourably influences the clinical course of the disease [88]. As a matter of fact, by increasing the erythrocyte susceptibility to triggers of eryptosis, sickle-cell trait, betathalassemia-trait, $\mathrm{Hb}-\mathrm{C}$ and G6PD-deficiency protect against a severe course of malaria [43, 


\section{Cellular Physiology Cell Physiol Biochem 2015;37:1629-1640

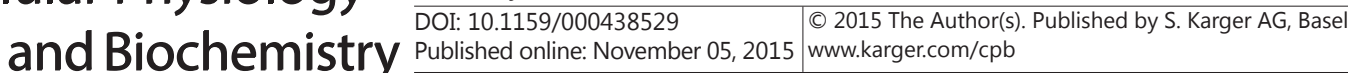 \\ Bouguerra et al.: Embelin-Induced Eryptosis}

89-91]. Along those lines, iron deficiency [92] and treatment with lead [92], chlorpromazine [93] or NO synthase inhibitors [93] counteract parasitemia by increasing the erythrocyte susceptibility to triggers of eryptosis [88]. It is tempting to speculate that embelin may accelerate phosphatidylserine translocation in Plasmodium infected erythrocytes.

On the other hand, embelin may aggravate anaemia in clinical conditions with enhanced phosphatidylserine translocation, including dehydration [72], hyperphosphatemia [83], chronic kidney disease (CKD) [72, 94-96], Hemolytic-uremic syndrome [97], diabetes [98], liver failure [99], malignancy [100], sepsis [101] and Wilsons disease [102]. Phosphatidylserine exposing erythrocytes further adhere to the vascular wall [103], trigger blood clotting and elicit thrombosis [104-106]. By stimulating phosphatidylserine translocation, embelin may thus impair microcirculation [44, 104, 107-110].

\section{Conclusion}

Embelin triggers phosphatidylserine translocation in the erythrocyte cell membrane, an effect paralleled by and in part due to ceramide formation.

\section{Acknowledgements}

The authors acknowledge the meticulous preparation of the manuscript by Tanja Loch. The study was supported by the Deutsche Forschungsgemeinschaft and Open Access Publishing Fund of Tuebingen University.

\section{Disclosure Statement}

The authors declare that they have nothing to disclose.

\section{References}

1 Joy B, Kumar SN, Radhika AR, Abraham A: Embelin (2,5-Dihydroxy-3-undecyl-p-benzoquinone) for photodynamic therapy: study of their cytotoxicity in cancer cells. Appl Biochem Biotechnol 2015;175:1069-1079.

2 Poojari R: Embelin - a drug of antiquity: shifting the paradigm towards modern medicine. Expert Opin Investig Drugs 2014;23:427-444.

3 Dai Y, Jiao H, Teng G, Wang W, Zhang R, Wang Y, Hebbard L, George J, Qiao L: Embelin reduces colitisassociated tumorigenesis through limiting IL-6/STAT3 signaling. Mol Cancer Ther 2014;13:1206-1216.

4 Schaible AM, Traber H, Temml V, Noha SM, Filosa R, Peduto A, Weinigel C, Barz D, Schuster D, Werz O: Potent inhibition of human 5-lipoxygenase and microsomal prostaglandin E(2) synthase-1 by the anticarcinogenic and anti-inflammatory agent embelin. Biochem Pharmacol 2013;86:476-486.

5 Xue Z, Ge Z, Zhang K, Sun R, Yang J, Han R, Peng M, Li Y, Li W, Zhang D, Hao J, Da Y, Yao Z, Zhang R: Embelin suppresses dendritic cell functions and limits autoimmune encephalomyelitis through the TGF-beta/betacatenin and STAT3 signaling pathways. Mol Neurobiol 2014;49:1087-1101.

6 Peng M, Huang B, Zhang Q, Fu S, Wang D, Cheng X, Wu X, Xue Z, Zhang L, Zhang D, Da Y, Dai Y, Yang Q, Yao Z, Qiao L, Zhang R: Embelin inhibits pancreatic cancer progression by directly inducing cancer cell apoptosis and indirectly restricting IL-6 associated inflammatory and immune suppressive cells. Cancer Lett 2014;354:407-416.

$7 \quad$ Huang M, Tang SN, Upadhyay G, Marsh JL, Jackman CP, Shankar S, Srivastava RK: Embelin suppresses growth of human pancreatic cancer xenografts, and pancreatic cancer cells isolated from KrasG12D mice by inhibiting Akt and Sonic hedgehog pathways. PLoS One 2014;9:e92161. 


\section{Cellular Physiology Cell Physiol Biochem 2015;37:1629-1640 and Biochemistry Published online: November 05, 2015 $\begin{aligned} & \text { (c) } 2015 \text { The Author(s). Published by S. Karger AG, Basel } \\ & \text { www.karger.com/cpb }\end{aligned}$ \\ Bouguerra et al.: Embelin-Induced Eryptosis}

8 Jiang L, Hao JL, Jin ML, Zhang YG, Wei P: Effect of Embelin on TRAIL receptor 2 mAb-induced apoptosis of TRAIL-resistant A549 non-small cell lung cancer cells. Asian Pac J Cancer Prev 2013;14:6115-6120.

9 Peng M, Xu S, Zhang Y, Zhang L, Huang B, Fu S, Xue Z, Da Y, Dai Y, Qiao L, Dong A, Zhang R, Meng W: Thermosensitive injectable hydrogel enhances the antitumor effect of embelin in mouse hepatocellular carcinoma. J Pharm Sci 2014;103:965-973.

10 Wehrkamp CJ, Gutwein AR, Natarajan SK, Phillippi MA, Mott JL: XIAP antagonist embelin inhibited proliferation of cholangiocarcinoma cells. PLoS One 2014;9:e90238.

11 Yang T, Lan J, Huang Q Chen X, Sun X, Liu X, Yang P, Jin T, Wang S, Mou X: Embelin sensitizes acute myeloid leukemia cells to TRAIL through XIAP inhibition and NF-kappaB inactivation. Cell Biochem Biophys 2015;71:291-297.

12 Dai Y, Desano J, Qu Y, Tang W, Meng Y, Lawrence TS, Xu L: Natural IAP inhibitor Embelin enhances therapeutic efficacy of ionizing radiation in prostate cancer. Am J Cancer Res 2011;1:128-143.

13 Sahu BD, Anubolu H, Koneru M, Kumar JM, Kuncha M, Rachamalla SS, Sistla R: Cardioprotective effect of embelin on isoproterenol-induced myocardial injury in rats: possible involvement of mitochondrial dysfunction and apoptosis. Life Sci 2014;107:59-67.

14 Radhakrishnan N, Gnanamani A, Prasad NR, Mandal AB: Inhibition of UVB-induced oxidative damage and apoptotic biochemical changes in human lymphocytes by 2,5-dihydroxy-3-undecyl-1,4-benzoquinone (embelin). Int J Radiat Biol 2012;88:575-582.

15 Hill CA, Alexander ML, McCullough LD, Fitch RH: Inhibition of X-linked inhibitor of apoptosis with embelin differentially affects male versus female behavioral outcome following neonatal hypoxia-ischemia in rats. Dev Neurosci 2011;33:494-504.

16 Ahn KS, Sethi G, Aggarwal BB: Embelin, an inhibitor of X chromosome-linked inhibitor-of-apoptosis protein, blocks nuclear factor-kappaB (NF-kappaB) signaling pathway leading to suppression of NFkappaB-regulated antiapoptotic and metastatic gene products. Mol Pharmacol 2007;71:209-219.

17 Avisetti DR, Babu KS, Kalivendi SV: Activation of p38/JNK pathway is responsible for embelin induced apoptosis in lung cancer cells: transitional role of reactive oxygen species. PLoS One 2014;9:e87050.

18 Edderkaoui M, Lugea A, Hui H, Eibl G, Lu QY, Moro A, Lu X, Li G, Go VL, Pandol SJ: Ellagic acid and embelin affect key cellular components of pancreatic adenocarcinoma, cancer, and stellate cells. Nutr Cancer 2013;65:1232-1244.

19 Hu R, Yang Y, Liu Z, Jiang H, Zhu K, Li J, Xu W: The XIAP inhibitor Embelin enhances TRAIL-induced apoptosis in human leukemia cells by DR4 and DR5 upregulation. Tumour Biol 2015;36:769-777.

20 Hu R, Zhu K, Li Y, Yao K, Zhang R, Wang H, Yang W, Liu Z: Embelin induces apoptosis through downregulation of XIAP in human leukemia cells. Med Oncol 2011;28:1584-1588.

21 Huang Y, Lu J, Gao X, Li J, Zhao W, Sun M, Stolz DB, Venkataramanan R, Rohan LC, Li S: PEG-derivatized embelin as a dual functional carrier for the delivery of paclitaxel. Bioconjug Chem 2012;23:1443-1451.

22 Joy B, Sivadasan R, Abraham TE, John M, Sobhan PK, Seervi M, T RS: Lysosomal destabilization and cathepsin B contributes for cytochrome c release and caspase activation in embelin-induced apoptosis. Mol Carcinog 2010;49:324-336.

23 Li Y, Li D, Yuan S, Wang Z, Tang F, Nie R, Weng J, Ma L, Tang B: Embelin-induced MCF-7 breast cancer cell apoptosis and blockade of MCF-7 cells in the G2/M phase via the mitochondrial pathway. Oncol Lett 2013;5:1005-1009.

24 Mori T, Doi R, Kida A, Nagai K, Kami K, Ito D, Toyoda E, Kawaguchi Y, Uemoto S: Effect of the XIAP inhibitor Embelin on TRAIL-induced apoptosis of pancreatic cancer cells. J Surg Res 2007;142:281-286.

25 Park SY, Lim SL, Jang HJ, Lee JH, Um JY, Kim SH, Ahn KS, Lee SG: Embelin induces apoptosis in human glioma cells through inactivating NF-kappaB. J Pharmacol Sci 2013;121:192-199.

26 Siegelin MD, Gaiser T, Siegelin Y: The XIAP inhibitor Embelin enhances TRAIL-mediated apoptosis in malignant glioma cells by down-regulation of the short isoform of FLIP. Neurochem Int 2009;55:423-430.

27 Singh B, Guru SK, Sharma R, Bharate SS, Khan IA, Bhushan S, Bharate SB, Vishwakarma RA: Synthesis and anti-proliferative activities of new derivatives of embelin. Bioorg Med Chem Lett 2014;24:4865-4870.

28 Sumalatha KR, Abiramasundari G, Chetan GK, Divya T, Sudhandiran G, Sreepriya M: XIAP inhibitor and antiestrogen embelin abrogates metastasis and augments apoptosis in estrogen receptor positive human breast adenocarcinoma cell line MCF-7. Mol Biol Rep 2014;41:935-946. 


\section{Cellular Physiology Cell Physiol Biochem 2015;37:1629-1640 \begin{tabular}{l|l|l|l} 
DOI: 10.1159/000438529 & $\begin{array}{l}\text { (c) } 2015 \text { The Author(s). Published by S. Karger AG, Basel } \\
\text { www.karger.com/cpb }\end{array}$
\end{tabular} \\ Bouguerra et al.: Embelin-Induced Eryptosis}

29 Taghiyev A, Sun D, Gao ZM, Liang R, Wang L: Embelin-induced apoptosis of HepG2 human hepatocellular carcinoma cells and blockade of HepG2 cells in the G2/M phase via the mitochondrial pathway. Exp Ther Med 2012;4:649-654.

30 Viault G, Babu KS, Gautier F, Barille-Nion S, Juin P, Tasseau O, Gree R: Hemisynthesis of selected embelin analogs and investigation of their proapoptotic activity against cancer cells. Med Chem 2013;9:1028-1034.

31 Wang A, Zhang B, Zhang J, Wu W, Wu W: Embelin-induced brain glioma cell apoptosis and cell cycle arrest via the mitochondrial pathway. Oncol Rep 2013;29:2473-2478.

32 Wang DG, Sun YB, Ye F, Li W, Kharbuja P, Gao L, Zhang DY, Suo J: Anti-tumor activity of the X-linked inhibitor of apoptosis (XIAP) inhibitor embelin in gastric cancer cells. Mol Cell Biochem 2014;386:143-152.

33 Chen J, Nikolovska-Coleska Z, Wang G, Qiu S, Wang S: Design, synthesis, and characterization of new embelin derivatives as potent inhibitors of X-linked inhibitor of apoptosis protein. Bioorg Med Chem Lett 2006;16:5805-5808.

34 Danquah M, Li F, Duke CB, 3rd, Miller DD, Mahato RI: Micellar delivery of bicalutamide and embelin for treating prostate cancer. Pharm Res 2009;26:2081-2092.

35 Lu J, Huang Y, Zhao W, Marquez RT, Meng X, Li J, Gao X, Venkataramanan R, Wang Z, Li S: PEG-derivatized embelin as a nanomicellar carrier for delivery of paclitaxel to breast and prostate cancers. Biomaterials 2013;34:1591-1600.

36 Nikolovska-Coleska Z, Xu L, Hu Z, Tomita Y, Li P, Roller PP, Wang R, Fang X, Guo R, Zhang M, Lippman ME, Yang D, Wang S: Discovery of embelin as a cell-permeable, small-molecular weight inhibitor of XIAP through structure-based computational screening of a traditional herbal medicine three-dimensional structure database. J Med Chem 2004;47:2430-2440.

37 Heo JY, Kim HJ, Kim SM, Park KR, Park SY, Kim SW, Nam D, Jang HJ, Lee SG, Ahn KS, Kim SH, Shim BS, Choi SH, Ahn KS: Embelin suppresses STAT3 signaling, proliferation, and survival of multiple myeloma via the protein tyrosine phosphatase PTEN. Cancer Lett 2011;308:71-80.

38 Kim SW, Kim SM, Bae H, Nam D, Lee JH, Lee SG, Shim BS, Kim SH, Ahn KS, Choi SH, Sethi G, Ahn KS: Embelin inhibits growth and induces apoptosis through the suppression of Akt/mTOR/S6K1 signaling cascades. Prostate 2013;73:296-305.

39 Reuter S, Prasad S, Phromnoi K, Kannappan R, Yadav VR, Aggarwal BB: Embelin suppresses osteoclastogenesis induced by receptor activator of NF-kappaB ligand and tumor cells in vitro through inhibition of the NF-kappaB cell signaling pathway. Mol Cancer Res 2010;8:1425-1436.

40 Schmidt K, Martens-Lobenhoffer J, Meinitzer A, Graier WF, Torres CM, Venema RC, Mayer B: Activation of endothelial nitric oxide synthase by the pro-apoptotic drug embelin: Striking discrepancy between nitric oxide-mediated cyclic GMP accumulation and L-citrulline formation. Nitric Oxide 2010;22:281-289.

41 Dai Y, Qiao L, Chan KW, Yang M, Ye J, Ma J, Zou B, Gu Q Wang J, Pang R, Lan HY, Wong BC: Peroxisome proliferator-activated receptor-gamma contributes to the inhibitory effects of Embelin on colon carcinogenesis. Cancer Res 2009;69:4776-4783.

42 Lang PA, Kaiser S, Myssina S, Wieder T, Lang F, Huber SM: Role of Ca2+-activated K+ channels in human erythrocyte apoptosis. Am J Physiol Cell Physiol 2003;285:C1553-C1560.

43 Lang E, Qadri SM, Lang F: Killing me softly - suicidal erythrocyte death. Int J Biochem Cell Biol 2012;44:1236-1243.

44 Abed M, Towhid ST, Mia S, Pakladok T, Alesutan I, Borst O, Gawaz M, Gulbins E, Lang F: Sphingomyelinaseinduced adhesion of eryptotic erythrocytes to endothelial cells. Am J Physiol Cell Physiol 2012;303:C991999.

45 Lau IP, Chen H, Wang J, Ong HC, Leung KC, Ho HP, Kong SK: In vitro effect of CTAB- and PEG-coated gold nanorods on the induction of eryptosis/erythroptosis in human erythrocytes. Nanotoxicology 2012;6:847856.

46 Maellaro E, Leoncini S, Moretti D, Del Bello B, Tanganelli I, De Felice C, Ciccoli L: Erythrocyte caspase-3 activation and oxidative imbalance in erythrocytes and in plasma of type 2 diabetic patients. Acta Diabetol 2013;50:489-495.

47 Zelenak C, Eberhard M, Jilani K, Qadri SM, Macek B, Lang F: Protein kinase CK1alpha regulates erythrocyte survival. Cell Physiol Biochem 2012;29:171-180.

48 Bhavsar SK, Gu S, Bobbala D, Lang F: Janus kinase 3 is expressed in erythrocytes, phosphorylated upon energy depletion and involved in the regulation of suicidal erythrocyte death. Cell Physiol Biochem 2011;27:547-556. 


\section{Cellular Physiology Cell Physiol Biochem 2015;37:1629-1640 and Biochemistry Published online: November 05, 2015 $\begin{aligned} & \text { (c) } 2015 \text { The Author(s). Published by S. Karger AG, Basel } \\ & \text { www.karger.com/cpb }\end{aligned}$ \\ Bouguerra et al.: Embelin-Induced Eryptosis}

49 Klarl BA, Lang PA, Kempe DS, Niemoeller OM, Akel A, Sobiesiak M, Eisele K, Podolski M, Huber SM, Wieder T, Lang F: Protein kinase C mediates erythrocyte "programmed cell death" following glucose depletion. Am J Physiol Cell Physiol 2006;290:C244-253.

50 Gatidis S, Zelenak C, Fajol A, Lang E, Jilani K, Michael D, Qadri SM, Lang F: p38 MAPK activation and function following osmotic shock of erythrocytes. Cell Physiol Biochem 2011;28:1279-1286.

51 Foller M, Sopjani M, Koka S, Gu S, Mahmud H, Wang K, Floride E, Schleicher E, Schulz E, Munzel T, Lang F: Regulation of erythrocyte survival by AMP-activated protein kinase. FASEB J 2009;23:1072-1080.

52 Foller M, Feil S, Ghoreschi K, Koka S, Gerling A, Thunemann M, Hofmann F, Schuler B, Vogel J, Pichler B, Kasinathan RS, Nicolay JP, Huber SM, Lang F, Feil R: Anemia and splenomegaly in cGKI-deficient mice. Proc Natl Acad Sci U S A 2008;105:6771-6776.

53 Zelenak C, Foller M, Velic A, Krug K, Qadri SM, Viollet B, Lang F, Macek B: Proteome analysis of erythrocytes lacking AMP-activated protein kinase reveals a role of PAK2 kinase in eryptosis. J Proteome Res 2011;10:1690-1697.

54 Lupescu A, Shaik N, Jilani K, Zelenak C, Lang E, Pasham V, Zbidah M, Plate A, Bitzer M, Foller M, Qadri SM, Lang F: Enhanced erythrocyte membrane exposure of phosphatidylserine following sorafenib treatment: an in vivo and in vitro study. Cell Physiol Biochem 2012;30:876-888.

55 Shaik N, Lupescu A, Lang F: Sunitinib-sensitive suicidal erythrocyte death. Cell Physiol Biochem 2012;30:512-522.

56 Jilani K, Qadri SM, Lang F: Geldanamycin-induced phosphatidylserine translocation in the erythrocyte membrane. Cell Physiol Biochem 2013;32:1600-1609.

57 Vota DM, Maltaneri RE, Wenker SD, Nesse AB, Vittori DC: Differential erythropoietin action upon cells induced to eryptosis by different agents. Cell Biochem Biophys 2013;65:145-157.

58 Zappulla D: Environmental stress, erythrocyte dysfunctions, inflammation, and the metabolic syndrome: adaptations to CO2 increases? J Cardiometab Syndr 2008;3:30-34.

59 Zbidah M, Lupescu A, Jilani K, Lang F: Stimulation of suicidal erythrocyte death by fumagillin. Basic Clin Pharmacol Toxicol 2013;112:346-351.

60 Abed M, Herrmann T, Alzoubi K, Pakladok T, Lang F: Tannic Acid induced suicidal erythrocyte death. Cell Physiol Biochem 2013;32:1106-1116.

61 Ahmed MS, Langer H, Abed M, Voelkl J, Lang F: The uremic toxin acrolein promotes suicidal erythrocyte death. Kidney Blood Press Res 2013;37:158-167.

62 Ghashghaeinia M, Cluitmans JC, Toulany M, Saki M, Koberle M, Lang E, Dreischer P, Biedermann T, Duszenko M, Lang F, Bosman GJ, Wieder T: Age Sensitivity of NFkappaB Abundance and Programmed Cell Death in Erythrocytes Induced by NFkappaB Inhibitors. Cell Physiol Biochem 2013;32:801-813.

63 Alzoubi K, Honisch S, Abed M, Lang F: Triggering of Suicidal Erythrocyte Death by Penta-O-galloyl-beta-dglucose. Toxins (Basel) 2014;6:54-65.

64 Jilani K, Lang F: Carmustine-induced phosphatidylserine translocation in the erythrocyte membrane. Toxins (Basel) 2013;5:703-716.

65 Jilani K, Enkel S, Bissinger R, Almilaji A, Abed M, Lang F: Fluoxetine induced suicidal erythrocyte death. Toxins (Basel) 2013;5:1230-1243.

66 Lupescu A, Bissinger R, Jilani K, Lang F: Triggering of suicidal erythrocyte death by celecoxib. Toxins (Basel) 2013;5:1543-1554.

67 Lupescu A, Jilani K, Zbidah M, Lang F: Patulin-induced suicidal erythrocyte death. Cell Physiol Biochem 2013;32:291-299.

68 Abed M, Zoubi KA, Theurer M, Lang F: Effect of dermaseptin on erythrocytes. Basic Clin Pharmacol Toxicol 2013;113:347-352.

69 Arnold M, Lang E, Modicano P, Bissinger R, Faggio C, Abed M, Lang F: Effect of nitazoxanide on erythrocytes. Basic Clin Pharmacol Toxicol 2014;114:421-426.

70 Oswald G, Alzoubi K, Abed M, Lang F: Stimulation of suicidal erythrocyte death by ribavirin. Basic Clin Pharmacol Toxicol 2014;114:311-317.

71 Bissinger R, Malik A, Jilani K, Lang F: Triggering of Erythrocyte Cell Membrane Scrambling by Salinomycin. Basic Clin Pharmacol Toxicol 2014;10.1111/bcpt.12250

72 Abed M, Feger M, Alzoubi K, Pakladok T, Frauenfeld L, Geiger C, Towhid ST, Lang F: Sensitization of erythrocytes to suicidal erythrocyte death following water deprivation. Kidney Blood Press Res 2013;37:567-578. 


\section{Cellular Physiology Cell Physiol Biochem 2015;37:1629-1640 and Biochemistry Published online: November 05, 2015 $\begin{aligned} & \text { (c) } 2015 \text { The Author(s). Published by S. Karger AG, Basel } \\ & \text { www.karger.com/cpb }\end{aligned}$ \\ Bouguerra et al.: Embelin-Induced Eryptosis}

73 Alzoubi K, Calabròa S, Bissinger R, Abed M, Faggio C, Lang F: Stimulation of Suicidal Erythrocyte Death by Artesunate. Cell Physiol Biochem 2014;34:2232-2244.

74 Arnold M, Bissinger R, Lang F: Mitoxantrone-induced suicidal erythrocyte death. Cell Physiol Biochem 2014;34:1756-1767.

75 Bissinger R, Fischer S, Jilani K, Lang F: Stimulation of Erythrocyte Death by Phloretin. Cell Physiol Biochem 2014;34:2256-2265.

76 Bissinger R, Lupescu A, Zelenak C, Jilani K, Lang F: Stimulation of eryptosis by cryptotanshinone. Cell Physiol Biochem 2014;34:432-442.

77 Bissinger R, Modicano P, Frauenfeld L, Lang E, Jacobi J, Faggio C, Lang F: Estramustine-induced suicidal erythrocyte death. Cell Physiol Biochem 2013;32:1426-1436.

78 Jacobi J, Lang E, Bissinger R, Frauenfeld L, Modicano P, Faggio C, Abed M, Lang F: Stimulation of erythrocyte cell membrane scrambling by mitotane. Cell Physiol Biochem 2014;33:1516-1526.

79 Lupescu A, Bissinger R, Herrmann T, Oswald G, Jilani K, Lang F: Induction of suicidal erythrocyte death by novobiocin. Cell Physiol Biochem 2014;33:670-680.

80 Lupescu A, Bissinger R, Warsi J, Jilani K, Lang F: Stimulation of erythrocyte cell membrane scrambling by gedunin. Cell Physiol Biochem 2014;33:1838-1848.

81 Malik A, Bissinger R, Calabro S, Faggio C, Jilani K, Lang F: Aristolochic Acid Induced Suicidal Erythrocyte Death. Kidney Blood Press Res 2014;39:408-419.

82 Tesoriere L, Attanzio A, Allegra M, Cilla A, Gentile C, Livrea MA: Oxysterol mixture in hypercholesterolemiarelevant proportion causes oxidative stress-dependent eryptosis. Cell Physiol Biochem 2014;34:10751089.

83 Voelkl J, Alzoubi K, Mamar AK, Ahmed MS, Abed M, Lang F: Stimulation of suicidal erythrocyte death by increased extracellular phosphate concentrations. Kidney Blood Press Res 2013;38:42-51.

84 Zhang R, Xiang Y, Ran Q, Deng X, Xiao Y, Xiang L, Li Z: Involvement of calcium, reactive oxygen species, and ATP in hexavalent chromium-induced damage in red blood cells. Cell Physiol Biochem 2014;34:1780-1791.

85 Zutshi U, Sharma SC, Kaul JL, Atal CK: Kinetic fate of potassium embelate, a non-narcotic centrally acting analgesic after oral and intravenous administration. Pharmacology 1990;40:179-184.

86 Newell AM, Yousef GG, Lila MA, Ramirez-Mares MV, de Mejia EG: Comparative in vitro bioactivities of tea extracts from six species of Ardisia and their effect on growth inhibition of HepG2 cells. J Ethnopharmacol 2010;130:536-544.

87 Harrison HE, Bunting H, Ordway NK, Albrink WS: The Pathogenesis of the Renal Injury Produced in the Dog by Hemoglobin or Methemoglobin. J Exp Med 1947;86:339-356.

88 Foller M, Bobbala D, Koka S, Huber SM, Gulbins E, Lang F: Suicide for survival--death of infected erythrocytes as a host mechanism to survive malaria. Cell Physiol Biochem 2009;24:133-140.

89 Ayi K, Giribaldi G, Skorokhod A, Schwarzer E, Prendergast PT, Arese P: 16alpha-bromoepiandrosterone, an antimalarial analogue of the hormone dehydroepiandrosterone, enhances phagocytosis of ring stage parasitized erythrocytes: a novel mechanism for antimalarial activity. Antimicrob Agents Chemother 2002;46:3180-3184.

90 Ayi K, Turrini F, Piga A, Arese P: Enhanced phagocytosis of ring-parasitized mutant erythrocytes: a common mechanism that may explain protection against falciparum malaria in sickle trait and betathalassemia trait. Blood 2004;104:3364-3371.

91 Cappadoro M, Giribaldi G, O'Brien E, Turrini F, Mannu F, Ulliers D, Simula G, Luzzatto L, Arese P: Early phagocytosis of glucose-6-phosphate dehydrogenase (G6PD)-deficient erythrocytes parasitized by Plasmodium falciparum may explain malaria protection in G6PD deficiency. Blood 1998;92:2527-2534.

92 Koka S, Huber SM, Boini KM, Lang C, Foller M, Lang F: Lead decreases parasitemia and enhances survival of Plasmodium berghei-infected mice. Biochem Biophys Res Commun 2007;363:484-489.

93 Koka S, Lang C, Niemoeller OM, Boini KM, Nicolay JP, Huber SM, Lang F: Influence of NO synthase inhibitor L-NAME on parasitemia and survival of Plasmodium berghei infected mice. Cell Physiol Biochem 2008;21:481-488.

94 Abed M, Artunc F, Alzoubi K, Honisch S, Baumann D, Foller M, Lang F: Suicidal erythrocyte death in endstage renal disease. J Mol Med (Berl) 2014;92:871-879.

95 Calderon-Salinas JV, Munoz-Reyes EG, Guerrero-Romero JF, Rodriguez-Moran M, Bracho-Riquelme RL, Carrera-Gracia MA, Quintanar-Escorza MA: Eryptosis and oxidative damage in type 2 diabetic mellitus patients with chronic kidney disease. Mol Cell Biochem 2011;357:171-179. 


\section{Cellular Physiology Cell Physiol Biochem 2015;37:1629-1640 \begin{tabular}{l|l|l|l} 
DOI: 10.1159/000438529 & O 2015 The Author(s). Published by S. Karger AG, Basel \\
www.karger.com/cpb
\end{tabular} \\ Bouguerra et al.: Embelin-Induced Eryptosis}

96 Polak-Jonkisz D, Purzyc L: Ca(2+) influx versus efflux during eryptosis in uremic erythrocytes. Blood Purif 2012;34:209-210; author reply 210.

97 Lang PA, Beringer O, Nicolay JP, Amon O, Kempe DS, Hermle T, Attanasio P, Akel A, Schafer R, Friedrich B, Risler T, Baur M, Olbricht CJ, Zimmerhackl LB, Zipfel PF, Wieder T, Lang F: Suicidal death of erythrocytes in recurrent hemolytic uremic syndrome. J Mol Med (Berl) 2006;84:378-388.

98 Nicolay JP, Schneider J, Niemoeller OM, Artunc F, Portero-Otin M, Haik G Jr, Thornalley PJ, Schleicher E, Wieder T, Lang F: Stimulation of suicidal erythrocyte death by methylglyoxal. Cell Physiol Biochem 2006;18:223-232.

99 Lang E, Gatidis S, Freise NF, Bock H, Kubitz R, Lauermann C, Orth HM, Klindt C, Schuier M, Keitel V, Reich M, Liu G, Schmidt S, Xu HC, Qadri SM, Herebian D, Pandyra AA, Mayatepek E, Gulbins E, Lang F, Haussinger D, Lang KS, Foller M, Lang PA: Conjugated bilirubin triggers anemia by inducing erythrocyte death. Hepatology 2015;61:275-284.

100 Qadri SM, Mahmud H, Lang E, Gu S, Bobbala D, Zelenak C, Jilani K, Siegfried A, Foller M, Lang F: Enhanced suicidal erythrocyte death in mice carrying a loss-of-function mutation of the adenomatous polyposis coli gene. J Cell Mol Med 2012;16:1085-1093.

101 Kempe DS, Akel A, Lang PA, Hermle T, Biswas R, Muresanu J, Friedrich B, Dreischer P, Wolz C, Schumacher U, Peschel A, Gotz F, Doring G, Wieder T, Gulbins E, Lang F: Suicidal erythrocyte death in sepsis. J Mol Med (Berl) 2007;85:273-281.

102 Lang PA, Schenck M, Nicolay JP, Becker JU, Kempe DS, Lupescu A, Koka S, Eisele K, Klarl BA, Rubben H, Schmid KW, Mann K, Hildenbrand S, Hefter H, Huber SM, Wieder T, Erhardt A, Haussinger D, Gulbins E, Lang F: Liver cell death and anemia in Wilson disease involve acid sphingomyelinase and ceramide. Nat Med 2007;13:164-170.

103 Borst O, Abed M, Alesutan I, Towhid ST, Qadri SM, Foller M, Gawaz M, Lang F: Dynamic adhesion of eryptotic erythrocytes to endothelial cells via CXCL16/SR-PSOX. Am J Physiol Cell Physiol 2012;302:C644-C651.

104 Andrews DA, Low PS: Role of red blood cells in thrombosis. Curr Opin Hematol 1999;6:76-82.

105 Chung SM, Bae ON, Lim KM, Noh JY, Lee MY, Jung YS, Chung JH: Lysophosphatidic acid induces thrombogenic activity through phosphatidylserine exposure and procoagulant microvesicle generation in human erythrocytes. Arterioscler Thromb Vasc Biol 2007;27:414-421.

106 Zwaal RF, Comfurius P, Bevers EM: Surface exposure of phosphatidylserine in pathological cells. Cell Mol Life Sci 2005;62:971-988.

107 Closse C, Dachary-Prigent J, Boisseau MR: Phosphatidylserine-related adhesion of human erythrocytes to vascular endothelium. Br J Haematol 1999;107:300-302.

108 Gallagher PG, Chang SH, Rettig MP, Neely JE, Hillery CA, Smith BD, Low PS: Altered erythrocyte endothelial adherence and membrane phospholipid asymmetry in hereditary hydrocytosis. Blood 2003;101:46254627.

109 Pandolfi A, Di Pietro N, Sirolli V, Giardinelli A, Di Silvestre S, Amoroso L, Di Tomo P, Capani F, Consoli A, Bonomini M: Mechanisms of uremic erythrocyte-induced adhesion of human monocytes to cultured endothelial cells. J Cell Physiol 2007;213:699-709.

110 Wood BL, Gibson DF, Tait JF: Increased erythrocyte phosphatidylserine exposure in sickle cell disease: flowcytometric measurement and clinical associations. Blood 1996;88:1873-1880. 